\title{
Analisis Potensi Wilayah Dan Sumber Daya Manusia Untuk Pengembangan Pusat Pelatihan Atletik Di Kabupaten Kerinci, Provinsi Jambi
}

\author{
Endarman Saputra ${ }^{1}$, David Iqroni ${ }^{1}$, Yudha Gusti Wibowo ${ }^{2}$ \\ ${ }^{1}$ Fakultas Ilmu Keolahragaan, Universitas Jambi \\ ${ }^{1}$ Program Pascasarjana, Universitas Jambi \\ Email korespondensi: Davidiqroni21@gmail.com
}

\begin{abstract}
ABSTRAK
Penelitian ini bertujuan untuk mnganalisis potensi wilayah dan sumberdaya manusia sebagai pusat pelatihan atletik di Kabupaten Kerinci. Penelitian ini dilakukan di Kabupaten Kerinci yang dilaksanakan pada bulan Mei - Agustus 2018. Penelitian dilakukan pada wilayah Kecamatan Kayu Aro. Populasi dalam penelitian ini adalah seluruh masyarakat yang berusia 7 sampai dengan 21 tahun. Metode pengambilan sampel dilakukan dengan cluster random sampling yang akan dijadikan cluster. Berdasarkan matriks EFAS dan IFAS dapat diketahui bahwa faktor eksternal dan faktor internal berada dalam posisi kuadran II yaitu didapat bahwa faktor internal berjumlah 2,910 dan faktor eksternal berjumlah 2.881 (2,910, 2,881), seperti terlihat pada gambar 4.1 bahwa hal ini membuktikan Kecamatan Kayu Aro memiliki kekuatan namun terkendala oleh ancaman yang berada di daerah lain sehingga harus memanfaatkan peluang dengan maksimal untuk mengatasi ancaman, dengan cara menjalin hubungan kerjasama yang baik dengan peemerintah daerah dan pemerintah pusat dan pihak-pihak terkait atau stakeholder keolahragaan, memaksimalkan tenaga keolahragaan yang memiliki kompetensi dengan latar belakang pendidikan sarjana olahraga supaya dapat memberikan kontribusi yang positif untuk pembinaan olahraga prestasi.
\end{abstract}

Kata Kunci : Atletik, Analisis SWOT, Matrix EFAS dan IFAS. 


\section{PENDAHULUAN}

Indonesia masih dihadapkan dengan berbagai permasalahan pembinaan olahraga. Beberapa kendala tersebut dapat disampaikan sebagai berikut, dimulai dengan minimnya dana untuk pembangunan olahraga, olahraga prestasi yang masih belum terintegrasi dengan sistem pendidikan nasional, belum optimalnya keterlibatan berbagai pihak terutama pihak swasta dalam pembinaan olahraga, Sarana dan prasarana olahraga yang minim serta strategi, peran dan prioritas dari pemerintah yang dirasa masih sangat kurang. Sejalan dengan hal tersebut, menurut pendapat lain, pembinaan olahraga belum terarah, Lemahnya peran lembaga/bidang penelitian dan pengembangan olahraga Masih terbatasnya sarana dan prasarana olahraga, masih sulitnya pemanfaatan fasilitas olahraga karena masih terbatas.

Secara nasional jumlah atlet atletik masih sedikit, sementara Indonesia memiliki beberapa potensi diantaranya sumberdaya alam (SDA) berupa letak geografis yang strategis bagi pengembangan olahraga yang membutuhkan daya tahan dan sumberdaya manusia (SDM) berupa penduduk yang banyak merupakan modal untuk mengembangkan pusat pelatihan atletik yang spesifik lokasi.

Beberapa penelitian telah menemukan bahwa latihan pada ketinggian dapat meningkatkan penampilan dibandingkan pada daerah dataran rendah. Dataran tinggi banyak sekali ditemukan didaerah Kabupaten Kerinci di Provinsi Jambi, karena letaknya yang berbukit-bukit.

Daya dukung usaha mencapai prestasi seorang atlet, selain dipengaruhi oleh sumber daya manusia juga dipengaruhi oleh wilayah atau potensi ketinggian dari suatu daerah yang biasa disebut dalam istilah olahraga adalah LHTH (live high-train high) yaitu situasi dimana para ilmuwan olahraga memanfaatkan daerah dataran tinggi untuk meningkatkan kinerja berolahraga, terutama cabang olahraga yang membutuhkan daya tahan. Dalam pembinaan atlet di suatu wilayah, maka perlu dianalisis potensi. Penelitian ini dilakukan di Kabupaten Kerinci yang dilakukan pada bulan Mei-Agustus 2018. Data yang digunakan dalam kegiatan ini meliputi data primer dan data sekunder. Data primer diperlukan untuk mendapatkan gambaran yang lebih luas dan komprehensip dari apa yang teramati dan terukur di lapangan. 
Data sekunder berupa keadaan umum wilayah, populasi dan atlet, jumlah penduduk, penggunaan fasilitas olahraga dan lainnya. Data sekunder diperoleh dari instansi terkait diantaranya: Badan Perencanaan Pembangunan Daerah (Bappeda), Badan Pusat Statistik (BPS), Dinas Pendidikan dan Kebudayaan, Dinas Keolahragaan Pemuda dan Olahraga, Kecamatan, dan Kantor Desa. Penelitian ini bertujuan untuk mengetahui potensi wilayah dan sumberdaya manusia untuk pembinaan atlet atletik di Kabupaten Kerinci, Provinsi jambi. Metode yang digunakan untuk melakukan analisis digunakan analisis sumber daya manusia dan angka partisipasi berolahraga masyarakat dan analisis potensi wilayah dengan menggunakan data-data yang diperlukan.

Perkebunan teh Kayu Aro, Kecamatan Kayu Aro yang terletak pada ketinggian 1600 m dari permukaan laut (dpl). Merupakan perkebunan teh tertinggi kedua setelah Himalaya. Kabupaten Kerinci memiliki wilayah dataran tinggi dan topografi yang berbukit dan bergunung dengan luas wilayah $3.355,27 \mathrm{~km} 2$. Karakter wilayah bergelombang serta berbukit-bukit sehingga membentuk eclave yang sangat luas dan sebagian ditutupi hutan lebat yang alami.

Kurangnya perkembangan atlet atletik disebabkan karena dihadapkan pada berbagai kendala yaitu sumberdaya manusia bidang keolahrgaan yang masih sedikit, dan kurangnya angka partisipasi berolahraga. Daya dukung pusat pelatihan atletik selain dipengaruhi oleh sumber daya manusia juga dipengaruhi oleh sumber daya alam serta yang diusahakan dan dapat dimanfaatkan oleh atlet sebagai tempat latihan.

Penelitian ini bertujuan untuk mengetahui potensi wilayah dan sumberdaya manusia untuk pengembangan pusat pelatihan atletik di Kabupaten Kerinci, Jambi.

\section{METODE PENELITIAN}

Pada penelitian ini akan digunakan dua pendekatan, yaitu pendekatan analisa data sekunder dan pendekatan survey. Pendekatan analisa data sekunder, digunakan untuk mengetahui potensi Kabupaten Kerinci.

\section{HASIL DAN PEMBAHASAN}

Pemerintah memiliki peran penting dalam pengembangan Keolahragaan dengan melibatkan masyarakat lokal. Yang dilakukan oleh masyarakat di bidang keolahragaan akan 
IJSSC: Indonesian Journal of Sport Science and Coaching

Vol. 1 No. 1 Febaruari 2019

Available on: https://online-journal.unja.ac.id/IJSSC

bergantung pada peluang dan kekuatan yang mereka miliki, insentif dan sumberdaya yang mereka miliki, dan akses mereka terhadap peningkatan keterampilan, pelatihan, sarana dan prasarana, yang tidak bisa terlepas dari kebijakan pemerintah.

Sebagai salah satu alternatif yang diharapkan mampu mengatasi minimnya jumlah atlet atletik di Kabupaten Kerinci, maka sudah sepatutnya keolahragaan mampu memberdayakan masyarakat, dimana maksud dari pemberdayaan tersebut adalah kondisi ideal dimana masyarakat mampu untuk terlibat secara aktif dalam pembinaan olahraga. Pemberdayaan masyarakat di Kabupaten Kerinci berada pada tahap dimana masyarakat mulai sadar akan pentingnya keolahragaan bagi kemajuan pembangunan olahraga. Meskipun jumlahnya kecil, namun anggota masyarakat tersebut mulai muncul dalam kelompokkelompok yang berkaitan dengan keolahragaan. Keberadaan kelompok-kelompok tersebut pada akhirnya harus direspons oleh pihak pemerintah daerah dengan pembentukan Kelompok - kelompok atau klub-klub olahraga.

Dalam melihat keterlibatan masyarakat lokal dalam pengembangan keolahragaan di Kabupaten Kerinci, Kecamatan Kayu Aro akan dijadikan sorotan utama dalam penelitian ini, karena kawasan tersebut dianggap memiliki potensi yang dapat menunjang pengembangan keolahragaan Kabupaten Kerinci. Pada kecamatan Kayu Aro, masyarakat lokal merespon bahwa keolahragaan dapat membawa manfaat dalam memberikan peluang pekerjaan.

Bentuk partisipasi masyarakat lokal yang ada tersebut selanjutnya akan dikategorikan kedalam tingkat partisipasi tertentu dengan mengacu pada tingkat partisipasi menurut Tosun (2006).

Pada aspek wilayah Kayu Aro memiliki kekuatan dikarenakan letaknya yang strategis. Adapaun ketinggian Kayu Aro adalah 1.600 mdpl yang artinya apabila dikaitkan dengan teori altitude training, maka akan sangat bermanfaat besar bagi peningkatan kualitas fisik atlet. Sedangkan kelemahan yang dimiliki yaitu, jauhnya lokasi dari pusat kota, yang diperkirakan kurang lebih 1 jam perjalanan. Sehingga dimungkinkan akan kesulitan para atlet nantinya untuk memenuhi kebutuhan mereka. 
IJSSC: Indonesian Journal of Sport Science and Coaching

Vol. 1 No. 1 Febaruari 2019

Available on: https://online-journal.unja.ac.id/IJSSC

Pada aspek lapangan olahraga, Kecamatan Kayu Aro memiliki kekuatan dengan 7 lapangan sepakbola. Sehingga sangat memungkinkan bagi pengembangan pusat pelatihan atletik, dikarenakan ada beberapa pilihan alternative yang dapat dimanfaatkan. Sedangkan kelemahan yang dihadapi adalah semua lapangan yang ada belum memiliki lintasan atletik yang standar atau layak untuk digunakan.

Pada aspek tenaga keolahragaan di Kecamatan Kayu Aro memiliki kekuatan yaitu, dengan memiliki sarjana olahraga yang bersumber dari guru-guru olahraga baik dari SD, SMP dan SMA yang berjumlah 18 orang. Selain itu terdapat juga beberapa pelatih olahraga, seperti pelatih sepakbola, bulutangkis dan lain-lain. Sedangkan kelemahan yang dihadapi adalah standar kompetensi kepelatihan yang dimiliki oleh para guru olahraga dan pelatih olahraga yang ada di Kecamatan kayu Aro.

Pada aspek dukungan Kecamatan Kayu Aro memiliki kekuatan yaitu, didukung oleh para stakeholder olahraga seperti dinas kepemudaan, olahraga, pariwisata dan kebudayaan serta KONI Kabupaten Kerinci yang mendukung pembinaan olahraga prestasi. Sedangkan kelemahan yaitu, kurangnya dukungan dari dinas pendidikan.

Tabel 1. Hasil Analisis Matrik IFAS

Faktor - Faktor Strategi Internal

Bobot Rating

Bobot $x$ Rating

\section{Kekuatan}

a. Wilayah

Letak wilayah yang diandalkan

0.150

4

b.Penduduk

Jumlah penduduk yang cukup

0.080

3

0.240

c. Lapangan Olahraga

Ketersediaan lapangan olahraga

0.100

3

0.300

d.Tenaga Keolahragaan

Ketersediaan SDM keolahragaan

0.090

2

0.180 
IJSSC: Indonesian Journal of Sport Science and Coaching

Vol. 1 No. 1 Febaruari 2019

Available on: https://online-journal.unja.ac.id/IJSSC

e.Dukungan

Dukungan diskeporabudpar, KONI dll

0.080

3

0.240

\section{Kelemahan}

a. Wilayah

Jauh dari pusat kota

0.100

3

0.300

b.Penduduk

Angka partisipasi berolahraga yang masih rendah

0.080

3

0.240

c. Lapangan Olahraga

Standard lapangan atau track atletik

0.150

2

0.300

d.Tenaga Keolahragaan

Standar kompetensi pelatih dan instruktur

0.080

3

0.240

e.Dukungan

Minimnya dukungan pemerintah.

0.090

0.270

Total

1

Tabel 2. Hasil Analisis Matrik EFAS

Faktor - Faktor Strategi Eksternal

Bobot Rating

Bobot x

Rating

\section{Peluang}

Kebutuhan atlet atletik

0.130

4

0.520

Tata kelola olahraga

0.117

3

0.351

Dukungan pemerintah pusat

0.110

0.330

Lingkungan masyarakat yang baik

0.130

3

0.390

\section{Ancaman}

Atlet atletik

Semakin ketatnya persaingan antar atlet

0.150

3

0.450 
IJSSC: Indonesian Journal of Sport Science and Coaching

Vol. 1 No. 1 Febaruari 2019

Available on: https://online-journal.unja.ac.id/IJSSC

Pusat pembinaan atletik didaerah yang lain juga

meningkat

$\begin{array}{lll}0.130 & 2 & 0.260\end{array}$

Tuntutan pemerintah daerah yang tinggi

0.110

2

0.220

Teknologi sport science

0.120

3

0.360

Total

1

Tabel 3. Selisih Faktor Internal dan Eskternal

\begin{tabular}{lllll}
\hline \multirow{2}{*}{ Uraian } & \multicolumn{3}{c}{ Faktor Internal } & \multicolumn{2}{c}{ Faktor Eksternal } \\
\cline { 2 - 5 } & Kekuatan & Kelemahan & Peluang & Ancaman \\
\cline { 2 - 5 } Bobot x Rating & 1,560 & 1,350 & 1,591 & 1,290 \\
Selisih & 0,210 & & & \\
& & & 0,301 & \\
\end{tabular}

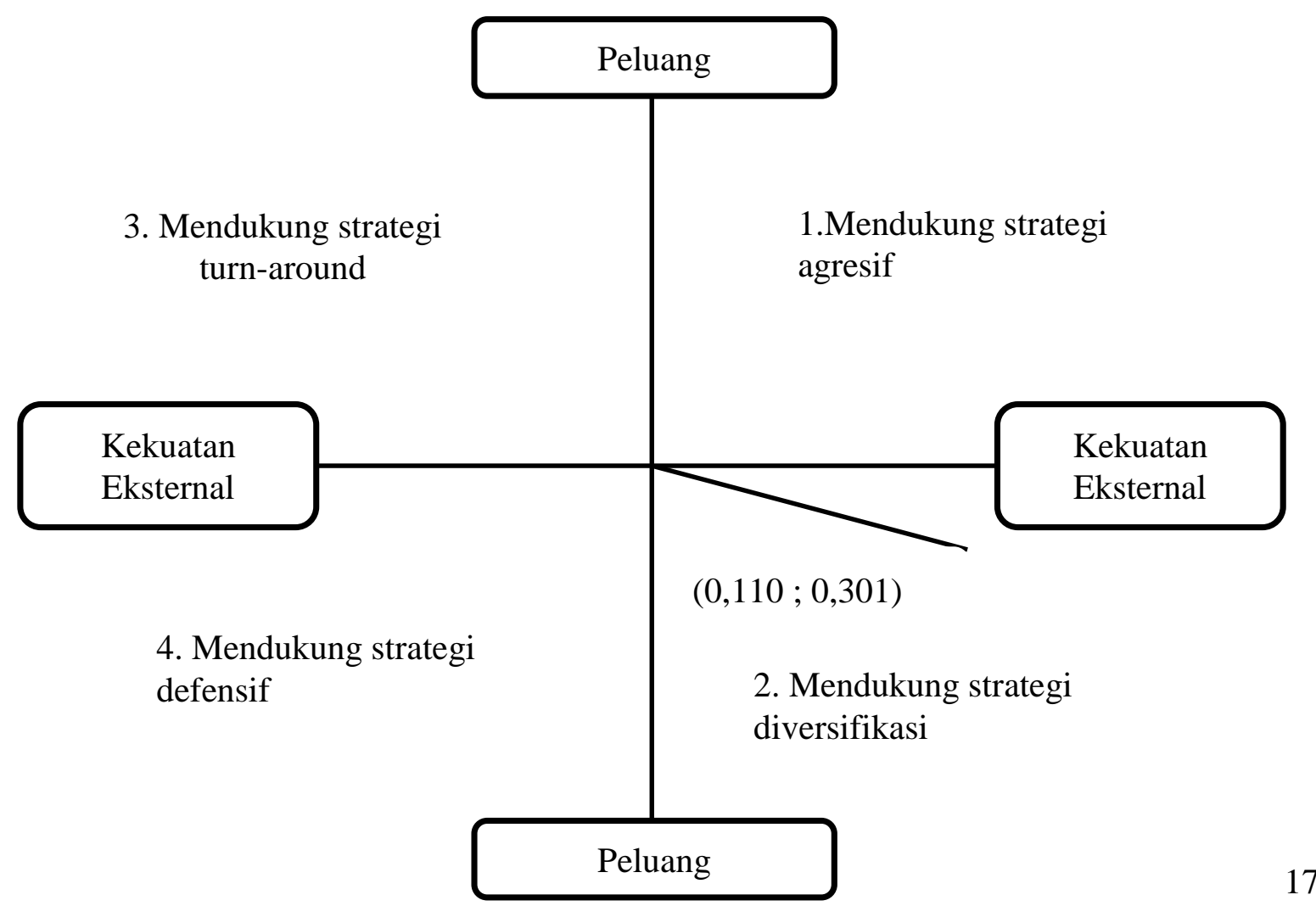


IJSSC: Indonesian Journal of Sport Science and Coaching

Vol. 1 No. 1 Febaruari 2019

Available on: https://online-journal.unja.ac.id/IJSSC

Tabel 4. Analisis Matrix SWOT

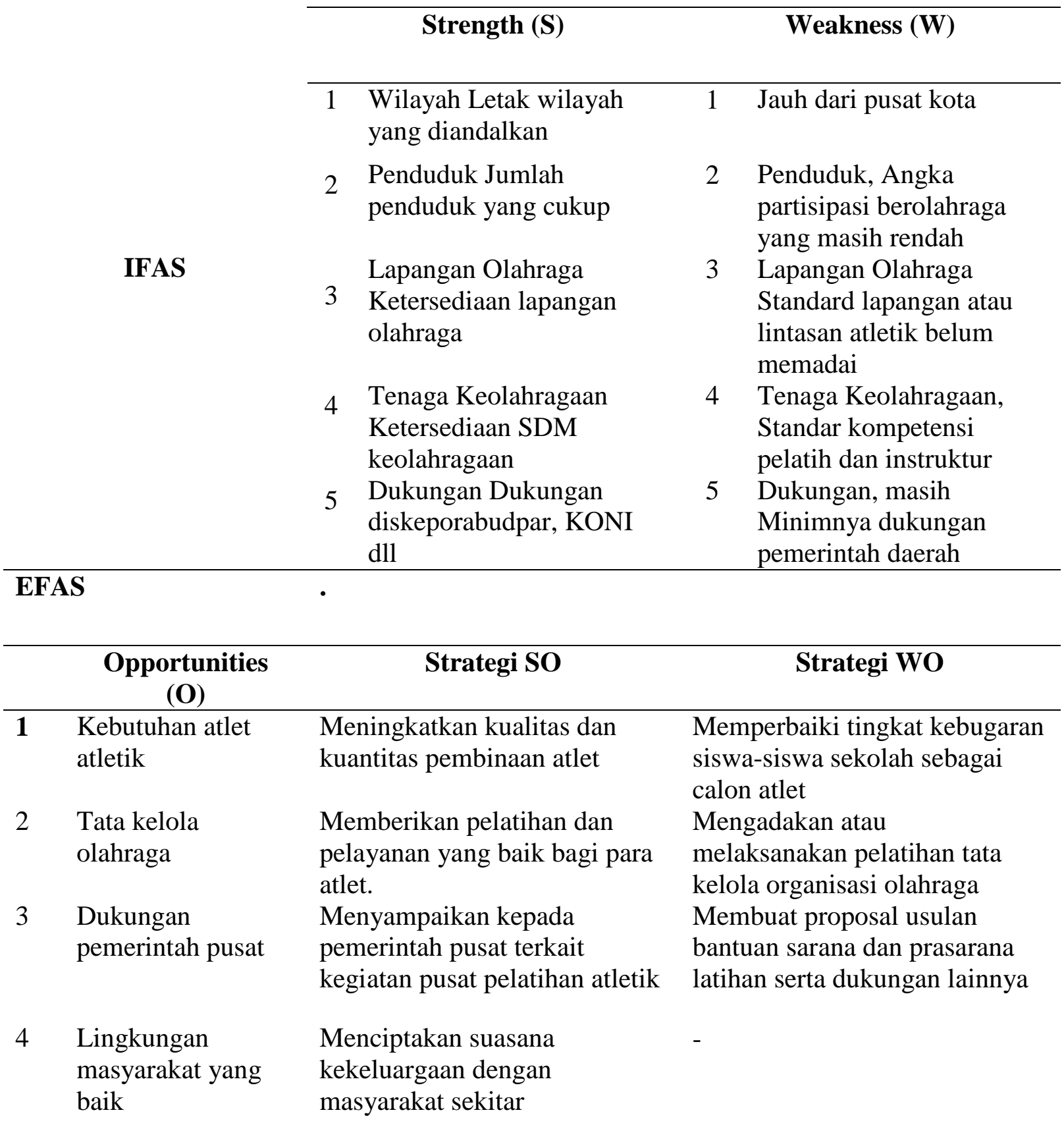

Threats (T)

Strategi ST

Strategi WT
1 Semakin ketatnya Meningkatkan kinerja serta
persaingan antar kemampuan atlet serta

atlet 
2 Pusat pembinaan atletik didaerah yang lain juga meningkat

3 Tuntutan pemerintah daerah yang tinggi

$4 \quad$ Teknologi sport science memberikan motivasi untuk berprestasi

Memacu semangat atlet untuk berprestasi. Memberikan pemahaman tentang proses pelatihan yang tidak mudah.
Melakukan sosialisasi dalam pencarian bibit atlet dan tes identifikasi bakat atlet

Mempertimbangkan untuk membeli peralatan latihan yang disesuaikan dengan kebutuhan IPTEK keolahrgaan.

Mengusahakan penerapan sport science dalam mendukung pencapaian prestasi

\section{KESIMPULAN DAN SARAN}

Berdasarkan landasan teori dan didukung oleh analisis data penelitian awal, maka untuk sementara dapat disimpulkan sebagai berikut.

1. Analisis SWOT yang digunakan dalam penelitian ini masih membutuhkan beberapa data pendukung yang lain.

2. Potensi wilayah yang ada di Kabupaten kerinci mempunyai potensi yang cukup besar untuk pengembangan pusat pelatihan olahraga atletik bila dikaitkan dengan altitude training.

3. Ketersediaan sumberdaya manusia masih dirasa kurang, sehingga diharapkan peran pemerintah untuk meningkatkan kuantitas dan kapasitas SDM keolahrgaan.

4. Hasil analysis dengan menggunakan SWOT dapat digunakan untuk menghitung nilai sumberdaya manusia dan angka partisipasi berolahraga masyarakat Kecamatan Kayu Aro. 


\section{DAFTAR PUSTAKA}

Burtscher M, Nachbauer W, Baumgartl P, Philadelphy M. Benefi ts of training at moderate altitude versus sea level training in amateur runners. Eur J Appl Physiol Occup Physiol. 1996;74:558-63.

B Sperlich, S. Achtzehn, M. de Marées, H. von Papen, J. Mester. Load management in elite German distance runners during 3-weeks of high-altitude training. Physiol Rep, 4 (12), 2016, e12845, doi: 10.14814/phy2.12845

Gore CJ, Hopkins WG. Counterpoint: positive effects of intermittent hypoxia (live high:train low) on exercise performance are not mediated primarily by augmented red cell volume. J Appl Physiol. 2005;99:2055.

Harsuki (2003) Manajemen Olahraga. Rajawali. Jakarta

Levine BD, Stray-Gundersen J. A practical approach to altitude training: where to live and train for optimal performance enhancement. Int J Sports Med. 1992;13 Suppl 1:S209-12.

Levine BD, Stray-Gundersen J. "Living high-training low": effect of moderate-altitude acclimatization with low-altitude training on performance. J Appl Physiol. 1997;83:102-12.

Rangkuti, F. 2000. Analisa SWOT. Teknik Membedah Kasus Bisnis. Penerbit PT Gramedia Pustaka Utama. Jakarta.

Undang-Undang No. 25 Tahun 2000. Program Pembangunan Nasional (PROPENAS) Jakarta: Sekretariat Negara Republik Indonesia.

Undang-Undang Republik Indonesia No. 3 Tahun 2005. Sistem Keolahrgaan Nasional. Jakarta

Wilber RL. Altitude training and athletic performance. Champaign, IL: Human Kinetics; 2004. 